\title{
Metastasis of Epidermoid Cervical Carcinoma Cell to The Orbit
}

\author{
Widiastuti ${ }^{1}$, Rachmi Fauziah Rahayu ${ }^{2}$, Djoko Susianto ${ }^{3}$, Rita Budianti ${ }^{4}$, Heru Priyanto ${ }^{5}$, \\ Ambar Moedigdo ${ }^{6}$, Soegiartiningsih ${ }^{7}$ \\ ${ }^{1}$ Department of Radiology, ${ }^{2}$ Department of Radiology, ${ }^{3}$ Department of Ophtalmology, ${ }^{4}$ Departement of Radiotherapy \\ Oncology, ${ }^{5}$ Department of Obstetrics and Gynecology Oncology, ${ }^{6}$ Departement of Pathology Anatomy, ${ }^{7}$ Resident \\ Department of Radiology Dr. Moewardi Public Hospital/Faculty of Medicine Sebelas Maret University, Surakarta, \\ Indonesia
}

\section{ARTICLE INFO}

\section{Article history}

Received 26 January 2017

Received in revised form 12 April 2018

Accepted 27 April 2018

Keywords:

Cervical Carcinoma, Metastasis, Orbit, Chemoradiation

Kata Kunci:

Kanker Serviks, Metastasis, Orbita,

Kemoradiasi

\begin{abstract}
Orbital metastases of cervical cancer cell are very rare. There is only one case reported in Dr. Moewardi Public Hospital Surakarta between 1999 and 2017. A 45-year-old woman was admitted with the upper right orbital lesion. She had not received a routine gynecologic examination for more than 10 years. She had normal chest X-ray. Abdominal ultrasonography revealed a heteroechoic lesion poor defined edge in cervix utery expands to corpus utery and rectum. Bilateral uropathy obstruction occured. Bone survey demonstrated osteolytic bone metastasis in the right supra orbital bone and a compression fracture of the twelfth thoracal spine. Head and orbital Computed Tomography (CT) scan, which revealed multiple metastatic lesions in the right orbital expanding to extra cranial, was performed. Our diagnosis was cervical cancer FIGO IV-B stage with distant metastasis thus chemoradiation was given. The aim of this report is to give more references regarding this complicated clinical condition.
\end{abstract}

\section{ABSTRAK}

Kanker serviks metastasis ke orbita sangat jarang terjadi. Hanya satu kasus yang dilaporkan di Rumah Sakit Umum Daerah Dr. Moewardi Surakarta antara tahun 1999 - 2017. Seorang wanita usia 45 tahun dirawat oleh karena lesi di orbita kanan atas sejak 2 bulan yang lalu. Pasien tersebut belum pernah mendapatkan pemeriksaan kandungan rutin selama lebih dari 10 tahun. Foto Chest $X$ Ray normal. Ultrasonografi abdomen tampak lesi heteroekoik batas tak tegas pada serviks uterus meluas ke korpus uterus dan rektum. Terjadi obstruksi uropati kanan dan kiri. Bone survei memperlihatkan gambaran metastasis tipe litik pada tulang supra orbita kanan dan fraktur kompresi pada tulang belakang toraks ke dua belas. Computed Tomography (CT) Kepala dan Orbita memperlihatkan beberapa lesi metastasis pada supra orbita kanan yang meluas ke tulang tengkorak. Diagnosis kami adalah kanker serviks tahap FIGO IV-B dengan metastasis jauh dan diberikan therapi kemoradiasi. Tujuan penulisan ini adalah untuk memberikan lebih banyak referensi data tentang kondisi klinis yang rumit ini.

\section{INTRODUCTION}

Based on WHO data year 2013, Indonesia is a country with the highest cervical carcinoma incidence worldwide. Every year more than 15,000 new cases of cervical cancer were detected and 8,000 cases led to mortality. It makes cervical cancer referred to as woman's number one killer disease in Indonesia. Cervical cancer in Indonesia progressively increases and the majority of sufferers are detected in terminal stage. Hematogenous spread is responsible for a more aggressive behaviour. It has been reported in the literature that there were only five cases of cervical cancer metastasizes to orbit., ${ }^{1,2}$ The most common primary sources of orbital metastases are breast (38-40\%), lung (20-29\%), gastrointestinal tract (12\%) and genito-urinary tract (12\%). ${ }^{1,3,4,6}$ Orbital metastases from carcinoma uterus, ovaries, bladder, pancreas, colon or rectum are very rare in

\footnotetext{
* Corresponding author: Widiastuti Department of Radiology Dr. Moewardi Public Hospital/Faculty of Medicine Sebelas Maret University Surakarta, Indonesia HP. 082134368592

E-mail: widiastutisprad@yahoo.co.id
} 
Japan, the United States and Europe. ${ }^{4}$ Eye metastases from cervical cancer are extremely rare but are known to occur; the orbit that is the extraocular muscles and the subconjunctival tissue being the reported sites of metastatic lesions. ${ }^{3-5,8}$ The orbit is an unusual site for metastatic cancer, approximately $2 \%-3 \%$ of patients with systemic cancer. ${ }^{8}$

\section{CASE REPORT}

A 45-year-old woman was admitted to Dr. Moewardi Public Hospital Surakarta with an upper right orbital lesion occurred 2 months before admission. The mass became larger and painful. The patient also complained about decreased right visual sight, diplopia, right sided headache and pelvic discomfort. Physical examination revealed a painful solid mass with the size of $5 \times 3 \mathrm{~cm}$ on her right frontal upper orbit. We found Right Eye Visus (REV) 6/7, Left Eye Visus (LEV) 6/7 and blepharoptosis in the right orbit. She had supel abdomen with suprapubic pain, Vaginal/Rectal Toucher (VT/RT) positive for fluor albus, infiltrated mass in the upper third vagina. Portio utery was enlarged, a $4 \mathrm{~cm}$ mass in diameter, infiltrated mass to parametrium and adnexa with the rigidity of $100 \% / 50 \%$. Laboratory findings demonstrated Haemoglobin of $11.4 \mathrm{~g} / \mathrm{dL}$, ureum $17 \mathrm{mg} / \mathrm{dL}$, creatinine $0.8 \mathrm{mg} / \mathrm{dL}$. Histopathology analysis of portio utery tissue revealed brown solid tissue $0.5 \mathrm{ml}$ with Non Keratinizing Moderately Differentiated Epidermoid carcinoma. Fine Needle Aspiration Biopsy (FNAB) of upper right orbit mass proved the epidermoid carcinoma metastases. Radiologic findings showed normal chest X-ray (Figure 1), a heteroechoic lesion poor defined edge in cervix uterus expands to corpus uterus and rectum, bilateral obstruction uropathy occurred in abdominal ultrasonography (Figure 2, 3). Bone survey demonstrated metastasis in the right frontal bone and a compression fracture of twelfth thoracal spine (Figure 4, 5, 6). Head and orbital CT Scan demonstrated multiple metastatic lesions in the frontal upper right orbit which expands to extra cranial (Figure 7, 8, 9, 10, 11). This patient was then diagnosed for cervical cancer FIGO IV-B stage with distant metastases to the right orbit, right frontal bone and twelfth thoracal spine. The patient was treated with chemoradiation. The patient received 5 FU - Cisplatin and radiation therapy with External Beam Radiation Therapy (EBRT) with the dose of $10 \times 300$ cGray for orbital mass and the twelfth thoracal until third lumbar spine. The patient had not received a routine gynecologic examination in more than 5 months because the patient decided to switch to herbal therapy that resulted in unsatisfied outcome. The mass in upper right orbit grew extremely large and became tension headache and then about 3 months later the patient passed away.

\section{Radiologic Findings:}
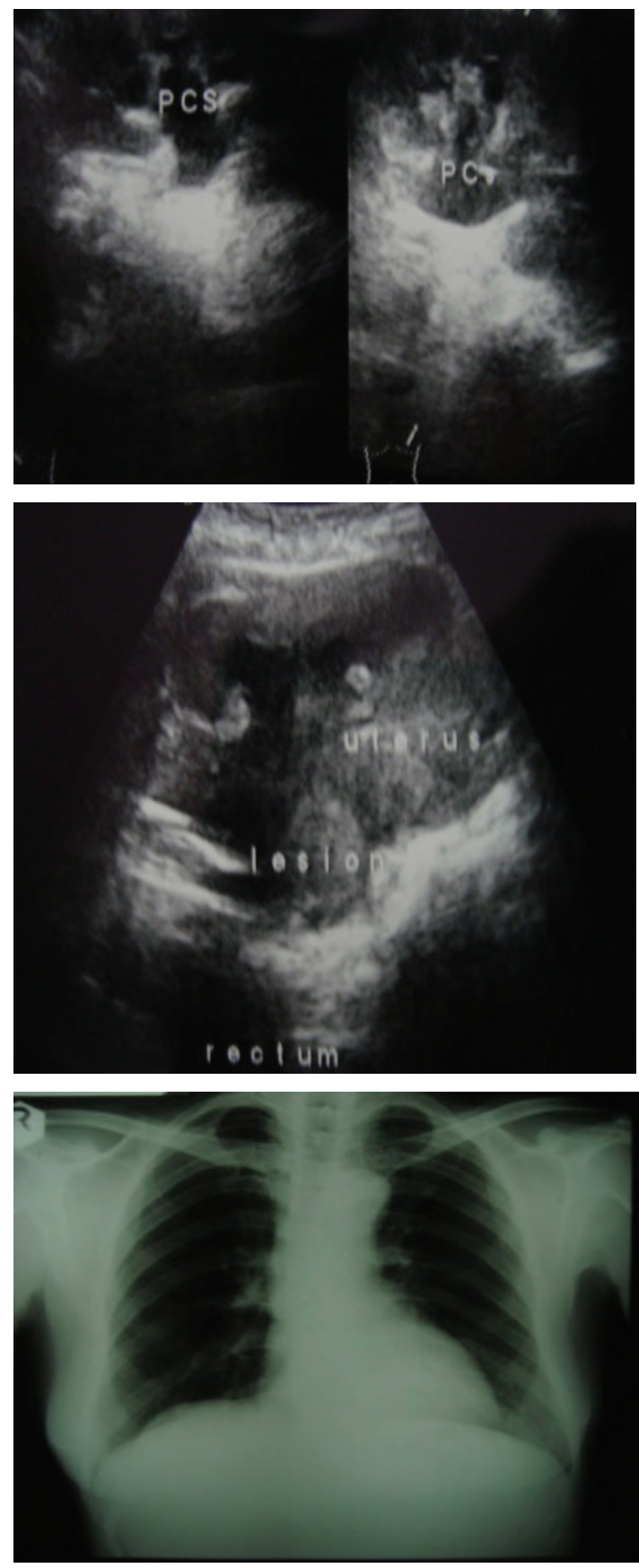

Figure 1. Chest X Ray. Normal

Figure 2, 3. Abdominal Ultrasonography revealed a heteroechoic lesion poor defined edge in cervix expands to corpus uterus and rectum. Bilateral obstruction uropathy with both of pelvicocaliceas system and ureter dilatations. 


\section{Bone Survey}
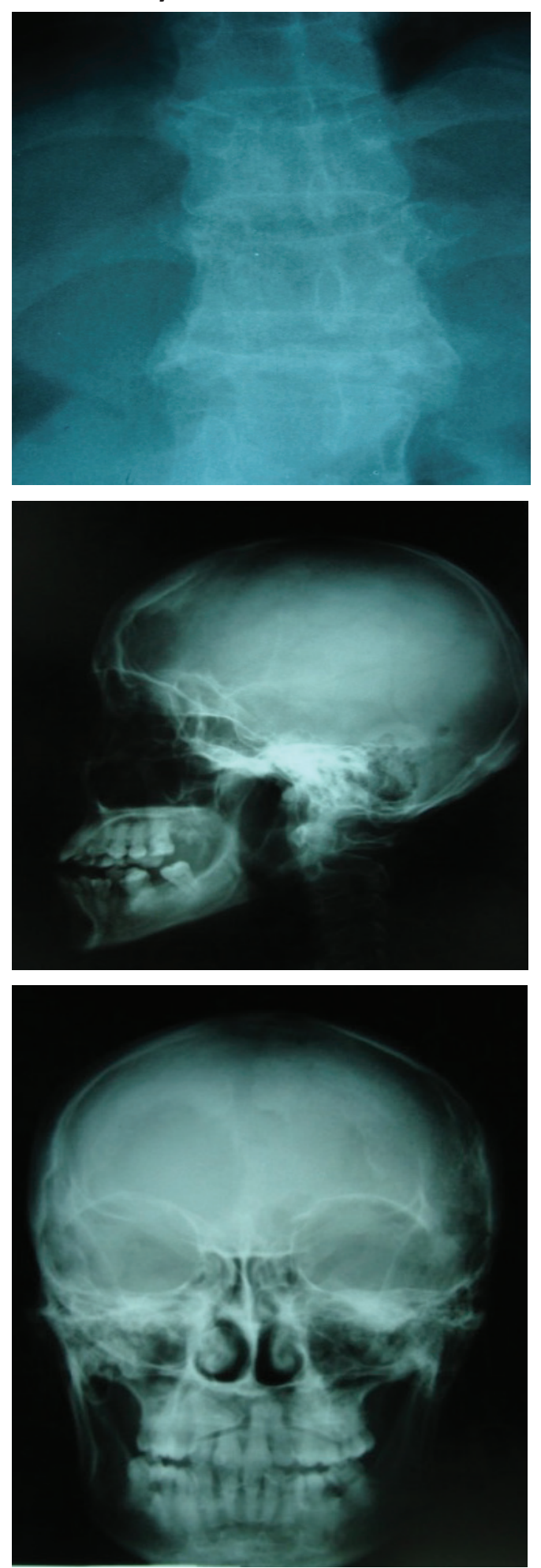

Figure 4, 5, 6. Skull X-ray demonstrated an osteolytic pattern in the right supra orbital bone with sharp sclerotic edge. Thoracal X Ray revealed a compression fracture of the twelfth thoracal spine

\section{Head CT Scan}
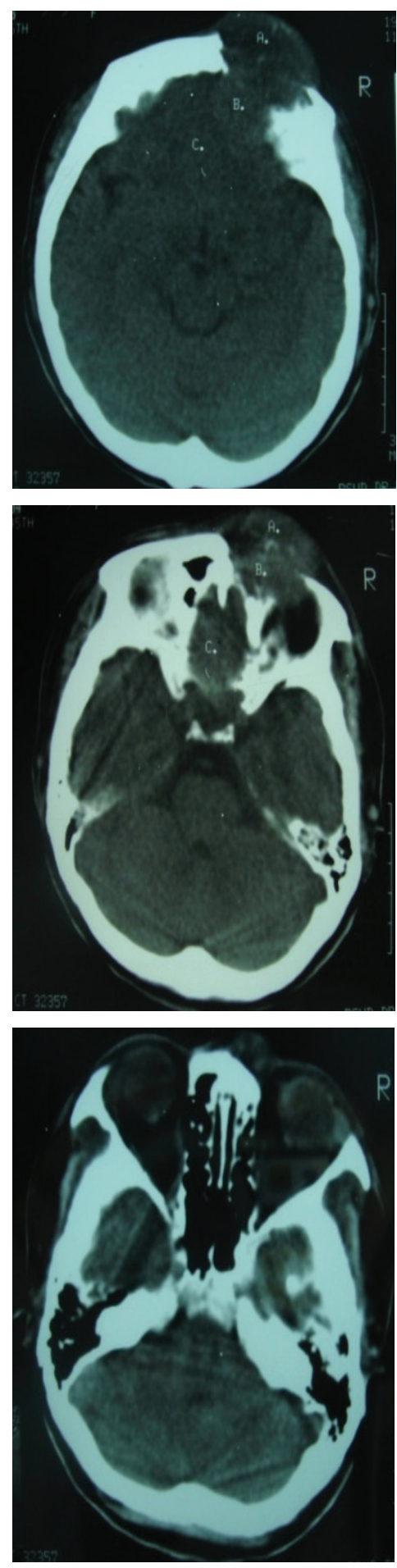

Figure 7, 8, 9. Plain Head CT scan: A hyperdense inhomogenous lesion in the frontal upper right orbit with the density of $34 .{ }^{8} \mathrm{HU}$, expanding to extra cranial. Osteodestruction involves right frontal bone, superior margin of right orbit, lateral wall of right cavum nasi and anterior base of cranium. There is no midline shift. 


\section{Orbital CT-Scan}
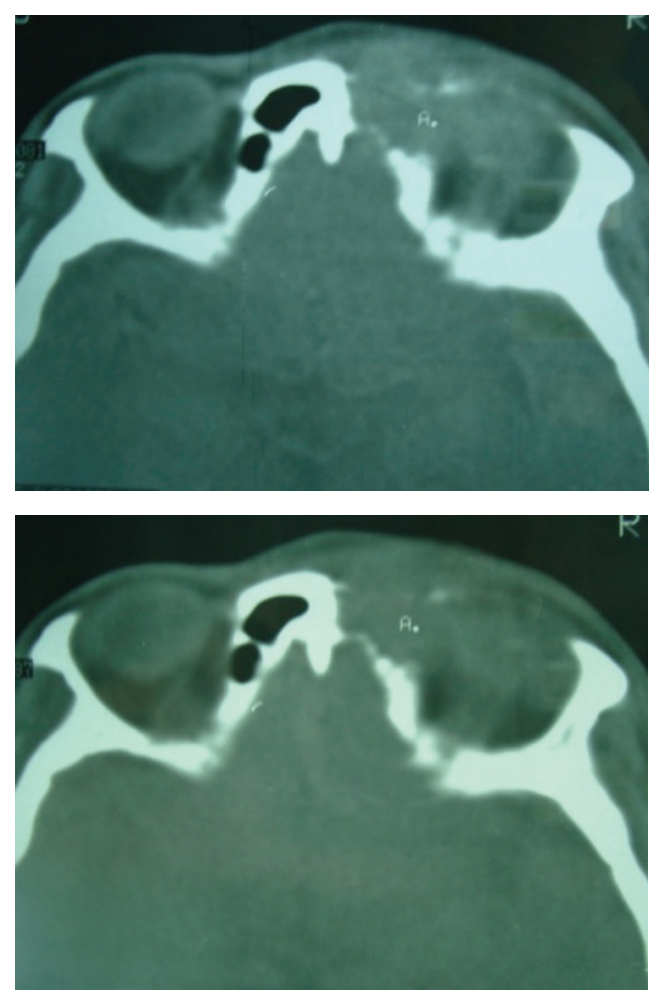

Figure 10, 11. Pre and post contrasted Orbital CT Scan revealed a hyperdense inhomogenous lesion, pre contrast density $52 \mathrm{HU}$, post contrast $81.3 \mathrm{HU}$, positive enhancement, in upper medial right orbit expands to medial margin of right orbit, levator palpebrae muscle, rectus medius muscle, right frontal sinus and right frontal lobe cerebri. Osteodestruction involves right frontal bone, superior margin of right orbit and lateral right nasal wall.

\section{DISCUSSION}

As previously described, cervical cancer metastasis occurs through local invasion of surrounding tissue and lymphatic dissemination. ${ }^{1}$ Hematogenous dissemination, although uncommon, is most likely to involve the liver, bones or lungs..$^{5-7}$ Hematogenous metastases to the orbit are less common than brain metastases because the ophthalmic veins are significantly smaller caliber vessels than the Central Nervous System (CNS) venous sinuses and are also much further away from the venous drainage of the spine. Cervical cancer metastatic to the CNS suggests migration via the venous plexus of Batson and the inner vertebral plexus invasion. ${ }^{1,7}$

The cells responsible for metastases must transverse the lungs before reaching the orbit through hema- togenous spread, although a few orbital metastases may be from retrograde venous flow through the vertebralbasilar plexus. In this case cervical cancer metastases was through vertebral-basilar plexus route to the right orbit because both lungs were normal. ${ }^{2,7}$

The Radiologic examinations of orbital metastasis are bone survey and head CT scan. Orbital imaging using CT and $\mathrm{MRI}$ are the principal means of evaluating orbital lesions. ${ }^{8}$ CT scan of the orbits can frequently show the presence of a mass, which often involves the orbital fat or extraocular muscles. ${ }^{3}$ CT scans are particularly useful in suspected cases of metastatic tumors with bone involvement. The bone lesions may be either hyperostotic (osteoblastic) or hypostotic (osteolytic). Muscle involvement usually discloses a solitary mass with irregular borders; other findings include bone destruction with or without intracranial or sinus extension. In this case the tumor metastases are located in superior medial region of extraconal right orbit, expanding to rectus medius muscle and levator palpebrae muscle that causes blepharoptosis and diplopia. Bone destruction in right frontal bone, nasal wall and superior margin orbit causes pain. The mass results in downward displacement of the globe. ${ }^{8}$ The accuracy of CT in assessment of stage IIIB- IVB disease is $92 \% .^{9}$ Definitive diagnosis of an orbital lesion includes an orbital biopsy (either FNA or open biopsy). ${ }^{3}$ Histologically, CNS metastases are seen more frequently with neuroendocrine and poorly differentiated Cervical Carcinoma. ${ }^{1,7}$ Histology of the orbital mass was similar to the Cervical cancer and reported as Epidermoid Cell Carcinoma moderate differentiation. ${ }^{8}$ Eighty percent to $90 \%$ of cervical carcinomas are of squamous cell origin, and the tumors are exophytic or primarily endocervical. ${ }^{9,10}$ Treatment of orbital metastases in particular is usually palliative and consists of radiation therapy with or without steroids and chemotherapy. The radiation therapy improved neurological symptoms, but additional chemotherapy increases survival significantly. ${ }^{9}$ Surgical excision may also be considered however the finding of orbital metastasis in and of itself is an ominous sign. Five FU - Cisplatin and Radiation Therapy with EBRT doses 10 x 300 cGray were given for orbit mass and twelfth thoracal until third lumbar spine. Most patients die within a year of diagnosis orbital metastasis. ${ }^{6}$ The 5 -year survival rate of cervical carcinoma IVB stage was below $20 \%$ and the recurrence frequency is high thus it is a bad prognosis. ${ }^{10}$ In this study case, the patient passed away within 8 months after the diagnosis. The most common malignant tumor of the eye is metastatic. ${ }^{11}$ Eye metastases are very rare in carcinoma of the cervix, and it is considered a prerequisite that pulmonary metastases precede ocular spread. ${ }^{12}$ 


\section{CONCLUSION}

Cervical cancer is the most commonly detected cancer in women aged over 25 years. It may spread through percontinuitatum, lymphogenous or haematogenous routes. Orbital metastasis of cancer originating from the cervix, despite its rarity, should be considered when an orbital mass of unknown etiology is present in women.

Ptosis, motility disturbance and pain are the commonest symptoms and sign of orbital metastasis. The onset of symptoms is typically rapid, unrelenting, and progressive over a few days and months.

The supportive examinations of orbital metastatic tumor are orbital CT scan and histopathology. The treatment of orbital metastases is usually palliative and consists of radiation therapy. Surgical excision and chemotherapy may also be considered, but their benefit has not been proven. Patients have poor outcomes despite attempts of treatment with chemotherapy, radiation and/or surgery, with death ranging from 3-10 months after the diagnosis of orbital metastasis. In our case death occurred within 8 months prior orbital metastasis diagnosis was established.

\section{REFERENCES:}

1. Pratibha Sareen., Roberta E. Blandon., Nicholas R. Binder., Darryl L. Wallace. Metastasis of Squamous Cell Cervical Carcinoma to the Orbit of the Eye. Gynecologic Oncology Reports 2 (2012) 83-86. https://www.ncbi.nlm.nih.gov/pmc/ articles/PMC3860768/

2. Wolfgang Dahnert. Radiology review manual. $6^{\text {th }}$ ed, Williams\&Wilkins, Philadelphia, 2007, p.1031

3. Payam Azadeh, Babak Hassanzadeh Rad and Ali Yaghobi Joybar. Orbital Metastasis from Breast Cancer Without Significant Changes in CT Scan and MRI. Iran J Radiology. 2016; 13(2):e20004.
4. Hirohiko Hayashida,Tsugio Amemiya,and Yoshinori Dake. Metastatic Orbital Tumors in Japan: a review of the literature. http://informahelthcare.com/loi/ope

5. Akshay Gopinathan Nair, Haresh T Asnani, Vinod C Mehta, Siddharth V Mehta, Rima S Pathak Metastatic adenocarcinoma of the cervix presenting as a choroidal mass: A case report and review of literature of cervical metastases to the eye

6. Choo CT and Lee HM. Orbital Metastasis from Carcinoma of Cervix. BJO,1997 ,81:330-331

7. Tangjitgamol, S., Levenback, C.F., Beller, U., Kavanagh, J.J., 2004. Role of surgical resec- tion for lung, liver, and central nervous system metastases in patients with gyneco- logical cancer: a literature review. Int. J. Gynecol. Cancer 14 (3), 399-422. http://onlinelibrary.wiley.com/doi/10.1111/j. 1048-891x.2004.14326.x/full

8. Mohammed A Eldesouky, Molham A Elbakary, Clinical and Imaging Characteristic of orbital metastasis lesion among Egyptian patient. Clinical Ophthalmology (Auckland, NZ). 2015;9:1683-1687. doi:10.2147/OPTH.S87788.

9. https://www.ncbi.nlm.nih.gov/pmc/articles/PMC4574802/

10. Harpreet K. Pannu, MD. Frank M. Corl, Elliot K. Fishman. CT Evaluation of Cervical Cancer: Spectrum of Disease. Radiographics 2001;21:1155-1168

11. Karuna Singh, Vinay Kumar, Suman Bhasker, Bidhu Kalyan Mohanti. Carcinoma cervix with metastasis to the orbit: A case report and review of literature. Journal of Cancer Research and Therapeutics. 2011 - Volume 7 - Issue 3. http://www.cancerjournal.net

12. Ferry and Font. Metastatic Carcinoma to eye and orbit. Arch Opthalmologic,vol 92,Oct 1974.

13. Hertzanu $Y$, Vellet $A D$, Fain $B A$, Ferreira MMV, and., Ninin DT, Eye Metastases in Carcinoma of The Cervix, a case report. S Afr J,1987,71:53-54 